\title{
Genesis and Parent Material Uniformity Appraisal of some Adjacent Soils to Bani Mazar-El Boiety Road, El Minia, Egypt
}

\author{
Moamen M. El Kady, Taher M. H. Yossif 1
}

\begin{abstract}
Perception of soil's history is an essential in addressing the imperious issues related to the sustainable agricultural development and land degradation in the hyper arid and arid regions. Therefore, the current work was undertaken to appraise of pedogenesis and parent material uniformity using Computer Controlled Scanning Electron Microscopy (CCSEM) technique. Five soil profiles (P1, P2, P3, P4, and P5) were selected for study on a topo-sequence model representing most of ground elevations of some soils adjacent to Bani Mazar-El Boiety road at western hyper arid desert of El Minia, Egypt $\left(3^{\circ} 15^{`} 40^{\prime \prime}\right.$ to $30^{\circ} 28^{`} 58^{\prime \prime} \mathrm{E}$ and $28^{\circ} 31^{\prime} 40^{\prime \prime}$ to $28^{\circ} 33^{\prime} 00^{\prime \prime N} 100$ to $170 \mathrm{~m}$ A.S.L.;54 $\mathrm{km}^{2}$ ). The data of CCSEM showed that the weighted means (\%) correlated to the ground elevation of Opaque minerals varied between 30.18 at $(150-160 \mathrm{~m} ; \mathrm{P4})$ and 43.81 at $(140-$ $150 \mathrm{~m}$; P2) while Pyroboles diverged between 40.85 at $(150-160 \mathrm{~m}$; P4) and 92.80 at (140-150 m; P5), Zircon (Z) ranged between 0.85 at $(140-150 \mathrm{~m} ; \mathrm{P2})$ and 15.79 at $(160-$ $170 \mathrm{~m}$; P3), Rutile (R) values were 2.14 at $(160-170 \mathrm{~m}$; P3) and 30.09 at $(150-160 \mathrm{~m}$; P4), contents of Tourmaline (T) were 0.72 at $(110-120 \mathrm{~m} ; \mathrm{P} 1)$ and 6.51 at $(150-160 \mathrm{~m}$; P4), Garnet varied between 0.17 at $(160-170 \mathrm{~m} ; \mathrm{P3})$ and 0.86 at $(140-150 \mathrm{~m}$; P2) within the studied soils, reflecting the heavy mineral suite was influenced by topo-sequence of the research area also indicating the study soils are recently formed, weakly developed, and have low effect of pedogenic processes. Irregular vertical distribution with depth of $Z / T, Z / R, Z / R+T$ ratios, and index figure proved that soil parent materials were stratified in nature and apparently formed of multi-depositional regimes. Scanning electron micrographs also confirmed that the investigated soils most probably transported and originated by water agent to distances not far away. The same conclusions have been indicated by applying the grain size analysis of sand fraction reported by Folk and Ward (1957).
\end{abstract}

Keywords: Pedogenesis; parent material uniformity; CCSEM; heavy minerals; top-sequence model; soil development; hyper arid desert; El Minia; Egypt.

\section{INTRODUCTION}

Further grasping of pedogenesis and parent material uniformity is substantial for perception of the back history of the soil. This is greatly required for sustainable use of land resources, preventing of soil degradation, and adopt suitable techniques for land use management. Pedogenesis is the tale of how soil brings into existence and acquires its current characteristics (Arnold, 2008). Uniformity of soil parent material is a

${ }^{1}$ Pedology Dept., Water Resources and Desert Soils Division, Desert Research Centre, Cairo, Egypt

Received July 11, 2017, Accepted August 3, 2017 postulate to evaluate soil forming processes. The selection of minerals resistant to chemical weathering in soils was a robust fundamental to assess their development and hence influence of the prevailing environmental conditions on its formation. Distinguishing between geological and pedological processes has been identified by examining the distribution of resistant minerals within the soil profile (Barshad, 1965; Brewer, 1976; Taboada et al., 2006). Those resistant minerals which have been commonly appointed for assessing pedogenesis and parent material uniformity are zircon $(Z)$, rutile $(R)$, tourmaline $(T)$ and quartz. The vertical homogeneity in their frequency distribution within the soil profile is considered as proof that the parent material was uniform. If their contents altogether $(\mathrm{Z}+\mathrm{R}+\mathrm{T})$ are more than 75 percent, the conclusion of pedological processes might be either are or were going on (Hurbert, 1962).

Discrimination of soil parent material uniformity is a worthwhile and valuable in many pedogenesis investigations due to it defines whether observed variations in morphological, physiochemical and mineralogical characteristics are the conclusion of genetic processes or to inherited divergences from the materials (Norton and Hall, 1984).

Hammad et al., (2009) investigated the genesis, nature and parent material uniformity of the soils belonging to old deltaic plain between Samalout to Baharia Oasis, West El Minia, Egypt. They reported that Opaques were the most abundant minerals while the non-opaque minerals were less considerable. They pointed out that among either layers or sites the weathering ratios of soil samples showed irregular distribution pattern. They attributed that to formations of soils from heterogeneous parent materials and/or multidepositional regimes. They concluded that soils were weakly developed and young from pedological point of view.

El Kady, (2008) assessed the pedogenesis and uniformity of parent materials in the limestone plateau of Maryut, Western desert, Egypt. It was noticed that the minerals of zircon, rutile, and tourmaline percentages have irregular distribution pattern within the pedons representing the plateau. It was referred to nonuniformity of the soil parent materials under appraising 
and most of the studied soils are inherited from multiparent materials. Furthermore, the water action was the dominant factor in soil formation.

The previous studies for evaluating soil genesis and its parent materials uniformity in Egypt have used the conventional methods for resistant minerals characterization i.e. polarized light microscopy using thin sections or manual Scanning Electron Microscopy(SEM) analysis. However, those classical procedures are generally wearisome, time-consuming and require intensive human-potential. Subsequently, decreasing the effort along with time-saving is effective substitution technology for quick characterization of the heavy and light minerals in soils, as is highly demanded like Computer Controlled Scanning Electron Microscopy (CCSEM).

CCSEM is a powerful tool and a fully automated technique for identifying the composition, size, and abundance of mineral type. It amalgamates between the traits of the couple SEM assignments: digital image analysis of backscattered electron micrographs and energy dispersive spectrometry (EDS) for chemical quantifications of the elements, (Keulen et al., 2012). Accordingly, CCSEM has become standard off-the-shelf technology and is widely applied in the ore industry for mineral liberation analysis.

The objectives of this work were to evaluate parent materials uniformity and pedogenesis of the soils adjacent to Bani Mazar-El Boiety road, El Minia governorate at western desert of Egypt. For achieving those goals, CCSEM technique was applied for identification the heavy-mineral suite of the sand fraction to understand better the nature of the soils occupying the research area.

\section{MATERIALS AND METHODS}

\section{The study area}

The site of investigation is pinpointing at Bani Mazar's Western Desert fringe, Egypt and lies between longitudes $30^{\circ} 15^{\circ} 40^{\prime \prime}$ and $30^{\circ} 28^{\circ} 58^{\prime \prime} \mathrm{E}$, and latitudes $28^{\circ} 31^{\prime} 40^{\prime \prime}$ and $28^{\circ} 33^{\circ} 00^{\prime \prime} \mathrm{N}$, covering approximately $54 \mathrm{~km}^{2}$ of geographical area (Fig. 1).Bedrock geology in the study area includes two units; (i) OligocenePleistocene gravel and sand (200 m thickness), where is occupying a vast area, and (ii) Limestone of Samalut and Minia Formations which are chalky and dense limestone, (Egyptian General Petroleum Corporation Conco Coral. 1987) (Fig. 2). The research area has four landform units: (i) plateau foot slope, (ii) table-land having almost flat topography, (iii) table-land having undulating topography, and (iv) depression. The soils generally belong to the order Entisols and could be placed, at sub-group level, to Typic Torriorthents and
Typic Torripsamments. In addition, there is a relatively limited area belonging to Lithic Torriorthents, (Yossif, 2017).

2. Selection of soil profile sites and macromorphological description

Five soil profiles were selected on basis of a toposequence transect (West to East, with a length about of $20 \mathrm{Km}$ ) representing most of the topographical variations (elevation 100 to $170 \mathrm{~m}$ A.S.L) within the area of study (Fig.1). The profiles up to a depth of approximately $80-150 \mathrm{~cm}$ were exposed and macromorphological features were described following the guidelines set by FAO (2006). The genetic horizons were described, and soil samples were collected from each of them (total soil samples $=15$ ) for mineralogical analyses (Table 1).

\section{Preparing soil samples for separation of heavy minerals}

Soil samples were air-dried and coarse fragments $>2$ $\mathrm{mm}$ were removed by sieving and the soil samples $(<2$ $\mathrm{mm}$ ) were prepared for estimation of heavy minerals using methods in Brewer (1964). Hence, the sand fractions were treated with $0.1 \mathrm{~N} \mathrm{HCl}$ for carbonate removal, $30 \% \mathrm{H}_{2} \mathrm{O}_{2}$ for organic matter and manganese oxides removal and sodium dithionite for free iron oxides removal and sodium dithionite for free iron oxides removal. The sand fractions were washed with distilled water to ensure the removal of soluble salts, dried and the fraction of $(63-125 \mu)$ was separated by dry sieving for heavy minerals examination. Separation of heavy minerals was carried out using the bromoform separation technique.

\section{Preparing heavy mineral samples for CCSEM analysis}

Aluminium (Al) stubs were washed with the isopropyl alcohol prior to use for the proper removal of dust particles and other contaminants. Then the heavy mineral particles were placed on Al stub coated with double sided adhesive tape. Al stub placed in the K550X sputter coater in which the heavy mineral samples were subjected to coating with gold ions by vaporizing and depositing gold at $18-20 \mathrm{~mA}$ current flow $20 \mathrm{~s}$. This was done for enhancing the conduction of the sample.

\section{CCSEM analysis for quantitative evaluation of heavy minerals}

The CCSEM analyses at the Egyptian Mineral Resources Authority (EMRA) and Société Générale de Surveillance (SGS) were undertaken using Scanning Electron Microscopy Model: Quanta 250 FEG (Field Emission Gun) attached with EDX Unit (Energy Dispersive X-ray Analyses), with accelerating voltage 


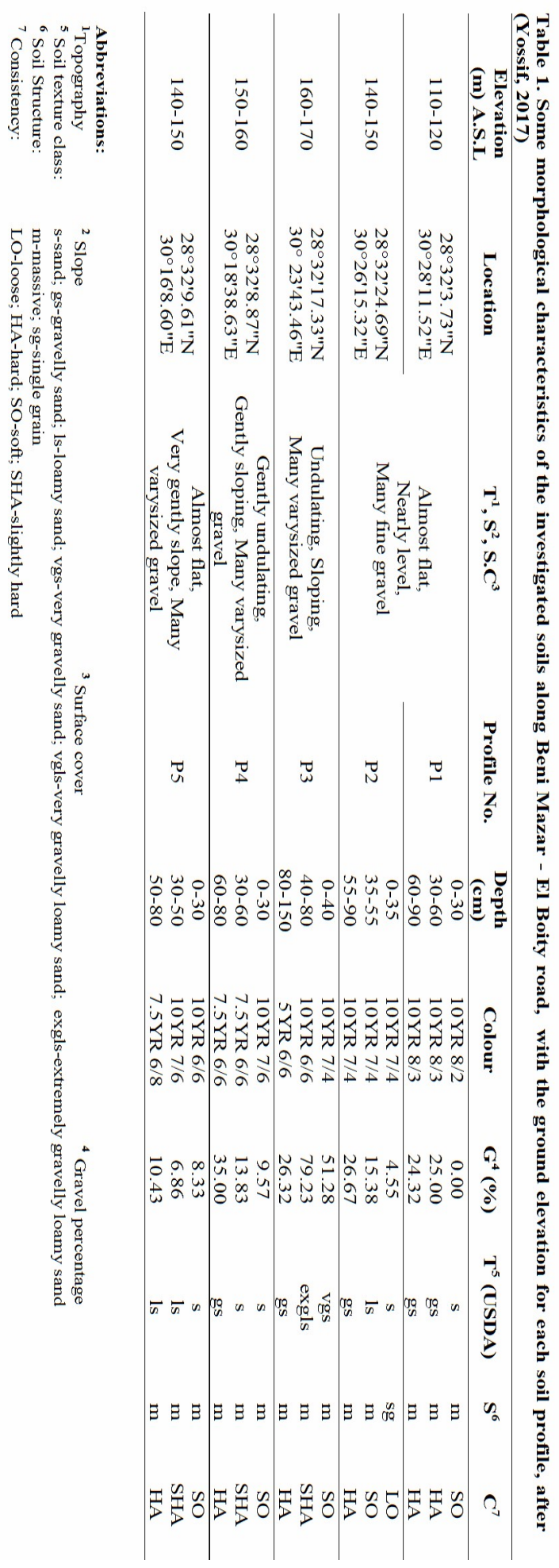




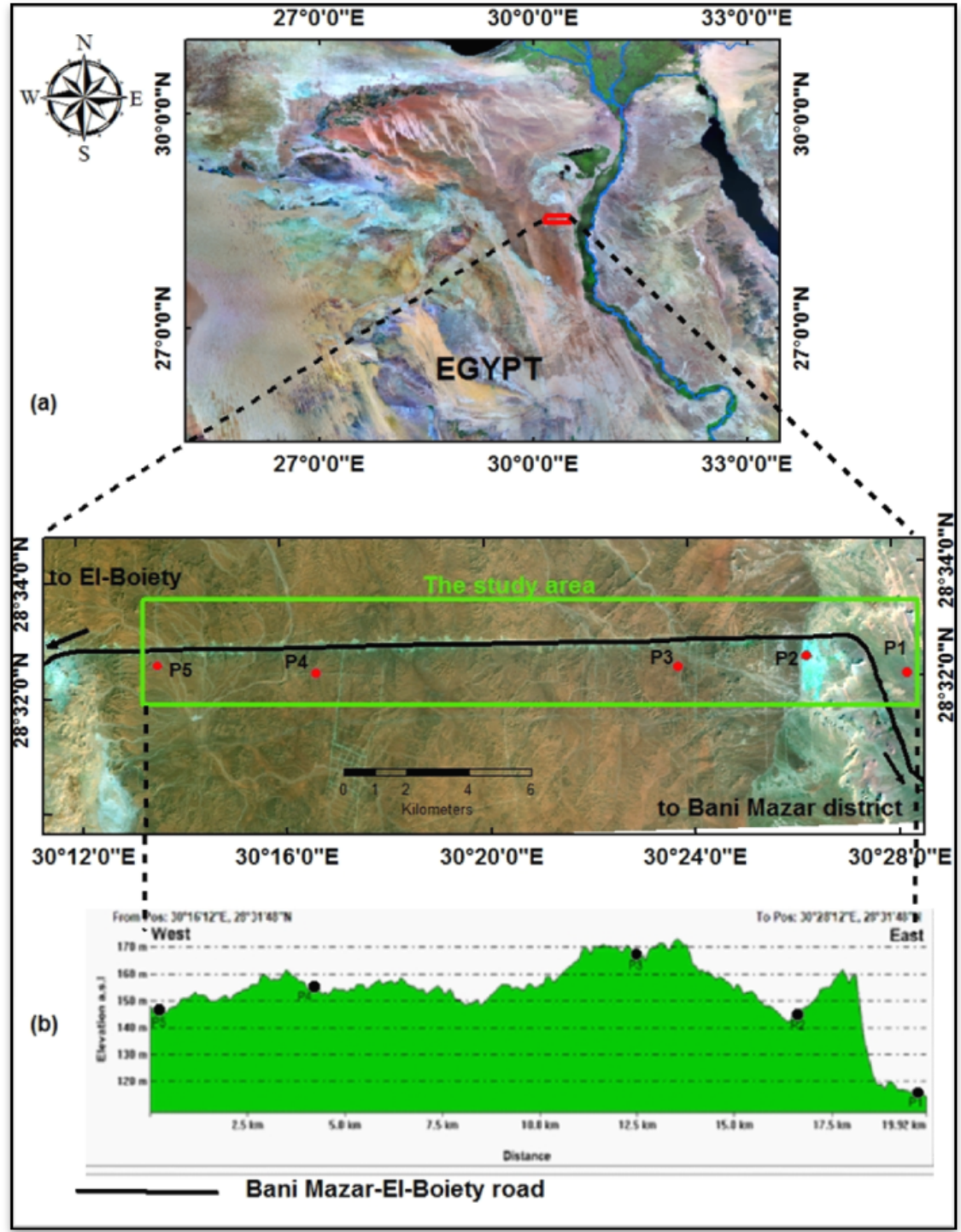

Fig 1. (a) Location of the study area along

(b) the topo-sequence model and localities of the selected soil profiles (100 to $170 \mathrm{~m}$ A.S.L)

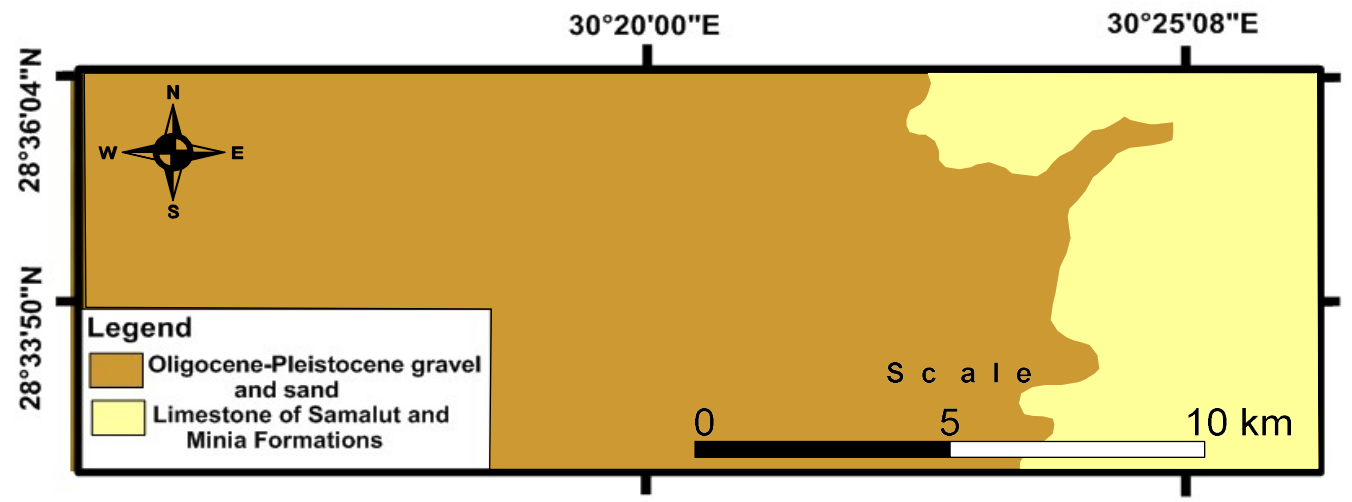

Fig.2. Geological map of the study area.

(After Egyptian General Petroleum Corporation - Conco Coral. 1987) 
30 K.V., magnification $14 \mathrm{x}$ up to 1000000 and resolution for Gun.1n. The sample was placed at a working distance of 12-13.5 $\mathrm{mm}$. The Thermo Noran System SIX software package at was applied to automatically collect X-ray spectra, grain size and morphology of all particles and to recalculate the data following the Proza $(\varphi \rho Z)$ data correction and the filtering quantification technique.

\section{Calculation (ZTR or Maturity Index), Uniformity Ratios, Index Figure and Grain Size Analyses.}

Zircon $(\mathrm{Z})$, rutile $(\mathrm{R})$ and tourmaline $(\mathrm{T})$ percentages were employed to calculate maturity index of the investigated soils using the following equation: ZTR= $(\mathrm{Z}+\mathrm{T}+\mathrm{R} /$ Non-opaque minerals)*100. Hubert, (1962) schemed to this equation and referred that the values of ZTR less than $75 \%$ implies immature to sub-mature sediments; ZTR more than $75 \%$ indicates matured sediments from the mineralogical point of view. The ratios of $\mathrm{Z} / \mathrm{R}, \mathrm{Z} / \mathrm{T}, \mathrm{Z} / \mathrm{R}+\mathrm{T}$, and index figure were calculated as evidences for uniformity or heterogeneity of parent material according to (Haseman and Marshall, 1945; Hammad, 1968; El Kady, 2008). The grain size analysis of sand fraction, on the other hand, was carried out according to the method outlined by Folk and Ward (1957), according to which cumulative percentage curves were plotted against Phi $(\varphi)$ grain diameter on arithmetic probability paper and statistical measures i.e. standard deviation and skewness were calculated.

\section{RESULTS AND DISCUSSION}

\section{Heavy mineral composition and distribution}

The analytical data of CCSEM indicate that the total percentage of heavy minerals in the studied soil profiles do not override $2.09 \%$ of the sample. Opaque, amphiboles, and pyroxenes constitute the greater allocation while other minerals like zircon, rutile, tourmaline, and garnet mostly occur in insignificant amounts. The opaque minerals (OM) comprise of iron oxides minerals, such as; magnetite, ilmenite, hematite, and goethite. The results show that the OM are found in appreciable amounts in most of samples, their content ranges vastly where the surface soils of profile (3) was the higher percentage rather than the others, (Table 2 ). The OM distributions with depth does not follow any specific trend, except in profile (1) where it increases with depth, while decreases at profile (3). In the series control section (SCS) which is representing the entire thickness of soil profile, the weighted means of the OM correlated to the ground elevation on the topo-sequence modelvary between $30.18 \%$ at $(150-160 \mathrm{~m} ; \mathrm{P} 4)$ to $43.81 \%$ at (140-150 m; P2) (Fig. 3).
Pyroboles group in the studied samples are represented mainly by Amphiboles and Pyroxenes. Our findings display that pyroboles are found in considerable proportions in all the investigated soil profiles. Pyroboles content in subsurface soils of profiles (5), (3), and (2) was higher compared to the other examined soils. The data illustrate irregular distribution with down vertical direction, excluding profile (5) where its pyroboles amount increases with depth (Table 2). In SCS, the weighted means of the pyroboles associated with the ground elevation diverge between $40.85 \%$ at $(150-160 \mathrm{~m} ; \mathrm{P} 4)$ and $92.80 \%$ at $(140-150 \mathrm{~m} ; \mathrm{P} 5)$ (Fig. 3).

Zircon is commonly found in inconsiderable amounts within the examined samples where it shows traces at the surface soils of profile (1) and its higher frequency content was observed at the top soils of profile (3)(Table 2). The ground elevations accomplice to zircon weighted means in SCS varied between $0.85 \%$ at (140-150 m; P2) and $15.79 \%$ at (160-170 m; P3) (Fig. 3).

Rutile is mostly detected in horizons of the studied profiles with small quantities. However, it was observed in higher contents at surface and subsurface soils of profiles (1\&2), respectively and along with the estimated samples of profile (4)(Table 2). The weighted means of the rutile correlated with ground elevations on the topo-sequence model ranged between $2.14 \%$ at (160-170 m; P3) and 30.09\% at (150-160 m; P4) (Fig. 3).

Tourmaline is generally noticed with little amounts within the examined samples where its maximum frequency was existed at surface soils of profile (4)(Table 2). Tourmaline weighted means linked to the ground elevations lies between $0.72 \%$ at $(110-120 \mathrm{~m}$; P1) and 6.51\% at (150-160 m; P4) (Fig. 3)

Garnet is recorded with nominal magnitudes in the investigated samples where its higher content occurs at surface soils of profile (2) (Table 2). The weighted means of garnet associated to the topo-sequence model of the study area varies between $0.17 \%$ at $(160-170 \mathrm{~m}$; P3) and $0.86 \%$ at (140-150 m; P2) (Fig. 3).

The relative raise in the weighted means (\%) of rutile, and tourmaline at the ground altitudes of $(\mathrm{P} 4$; $150-160 \mathrm{~m})$ and zircon at (P3; 160-170 m) compared to the other soil profiles, indicating that those minerals were influenced by topo-sequence of the research area. Additionally, the weighted means (\%) of the same resistant minerals were distributed in close quantities for each one of them separately in the low places of the study area (P1; 110-120 m), (P2; 140-150 m) while were 


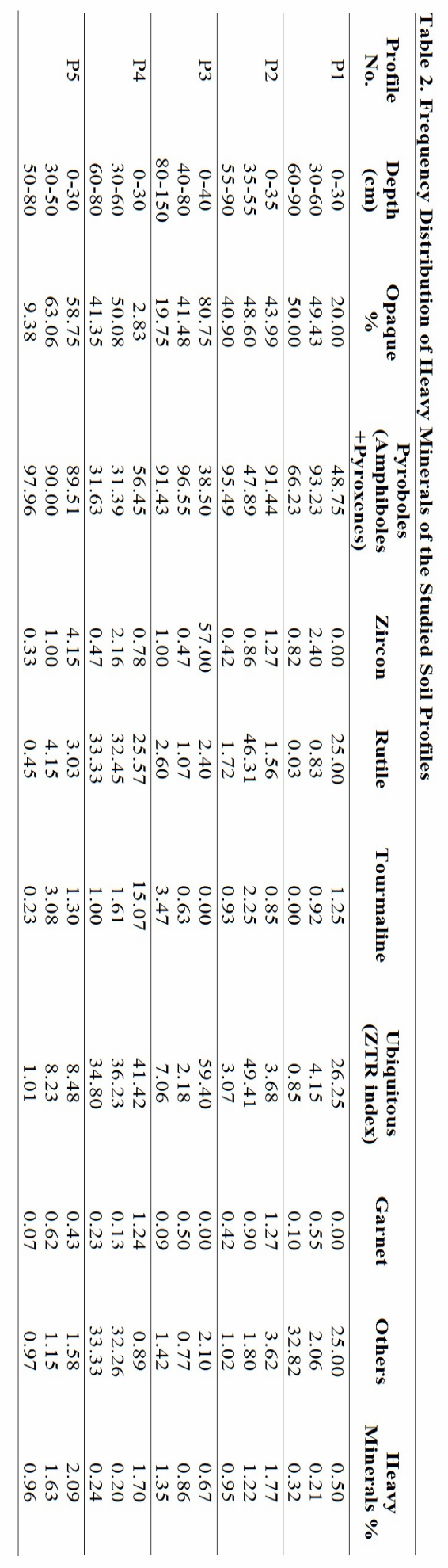




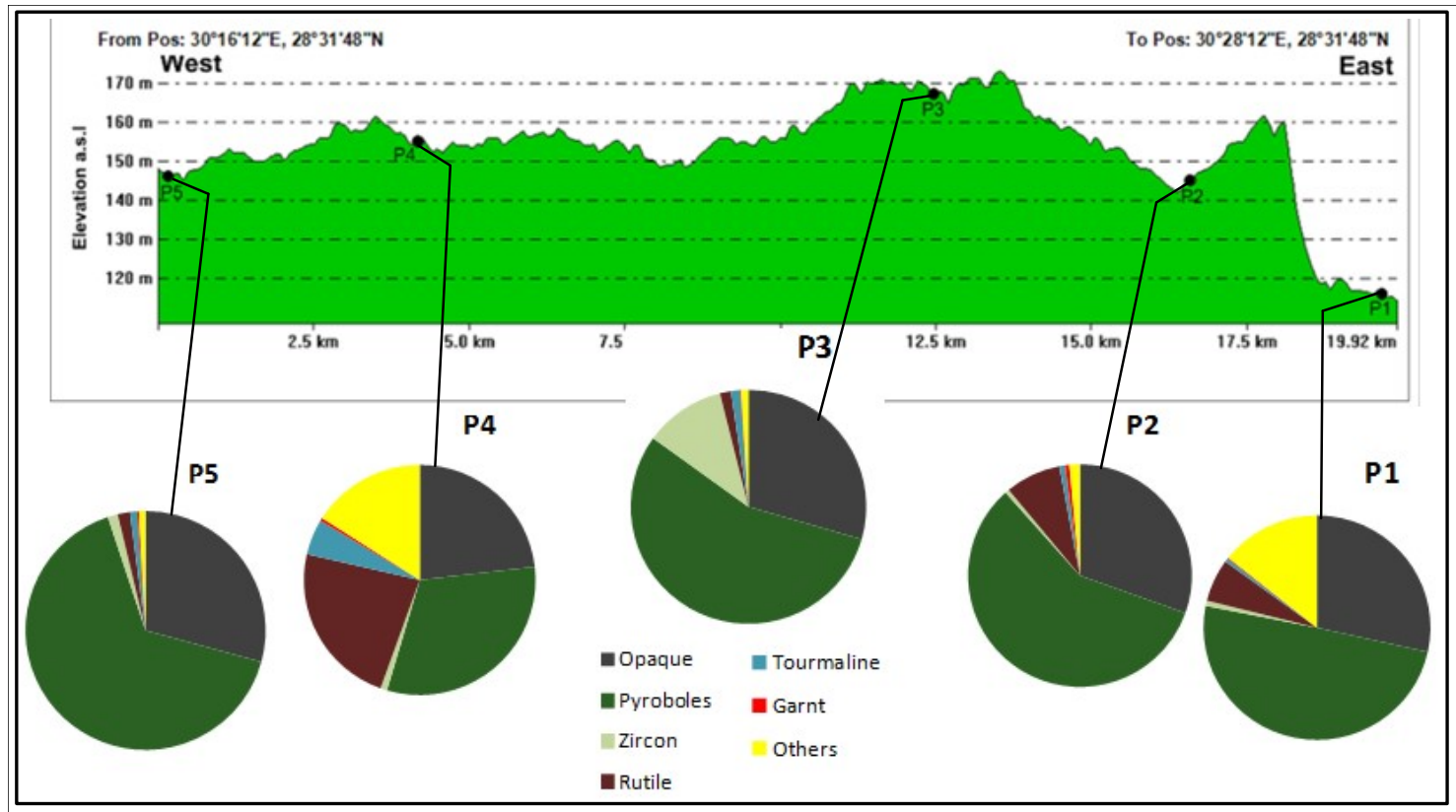

Fig. 3. Frequency distribution of the weighted means (\%) of heavy minerals in SCS linked to the topo-sequence model of the study area

existed in not fair percentages at the other pedons which reflects the geological variation and origin pluralism of the sediments belonging to the investigated area (Fig. 3).

Proportional increments were observed in contents of zircon at top soils of $\mathrm{P} 3$, rutile at surface soils of P1 and subsurface horizon of $\mathrm{P} 2$ and soils of $\mathrm{P} 4$, in addition to tourmaline at surface horizon of P4 in contrast with the other estimated samples (Table 2). However, (E1Desooky, 2009) interpreted the relatively higher proportions of resistant minerals areattributed to the origin of the sediments covering the study area.

\section{Soil development and its maturity assessment}

The results illustrated that the less stable minerals (Pyroboles) occur in high percentages at the examined profiles, while the more resistant minerals represented in zircon, rutile, and tourmaline (Ubiquitous) are in lower amounts. Moreover, existing of ZTR index values were less than $75 \%$ (Table 2), indicating that the study soils are less impacted by weathering, recently formed, weakly developed, immature, and are weakly affect by pedogenic processes. These feedbacks matched with soil classification data conducted by (Yossif, 2017).

Table 3. Ratios of the resistant minerals in the separated sand at the studied profiles

\begin{tabular}{|c|c|c|c|c|c|}
\hline Profile No. & Depth (cm) & $\mathbf{Z} / \mathbf{R}$ & $\mathrm{Z} / \mathrm{T}$ & $\mathbf{Z} / \mathbf{R}+\mathbf{T}$ & Index Figure \\
\hline \multirow{3}{*}{$\mathrm{P} 1$} & $0-30$ & 0.00 & 0.00 & 0.00 & 0.50 \\
\hline & $30-60$ & 2.89 & 2.60 & 1.37 & 0.21 \\
\hline & $60-90$ & 25.00 & 0.00 & 25.00 & 0.32 \\
\hline \multirow[t]{3}{*}{ P2 } & $0-35$ & 0.81 & 1.50 & 0.53 & 1.77 \\
\hline & $35-55$ & 0.02 & 0.38 & 0.02 & 1.22 \\
\hline & $55-90$ & 0.24 & 0.45 & 0.16 & 0.95 \\
\hline \multirow[t]{3}{*}{ P3 } & $0-40$ & 23.75 & 0.00 & 23.75 & 0.67 \\
\hline & $40-80$ & 0.44 & 0.75 & 0.28 & 0.86 \\
\hline & $80-150$ & 0.38 & 0.29 & 0.16 & 1.35 \\
\hline \multirow[t]{3}{*}{ P4 } & $0-30$ & 0.03 & 0.05 & 0.02 & 1.70 \\
\hline & $30-60$ & 0.07 & 1.34 & 0.06 & 0.20 \\
\hline & $60-80$ & 0.01 & 0.47 & 0.01 & 0.24 \\
\hline \multirow[t]{3}{*}{ P5 } & $0-30$ & 1.37 & 3.20 & 0.96 & 2.09 \\
\hline & $30-50$ & 0.24 & 0.33 & 0.14 & 1.63 \\
\hline & $50-80$ & 0.74 & 1.40 & 0.48 & 0.96 \\
\hline
\end{tabular}




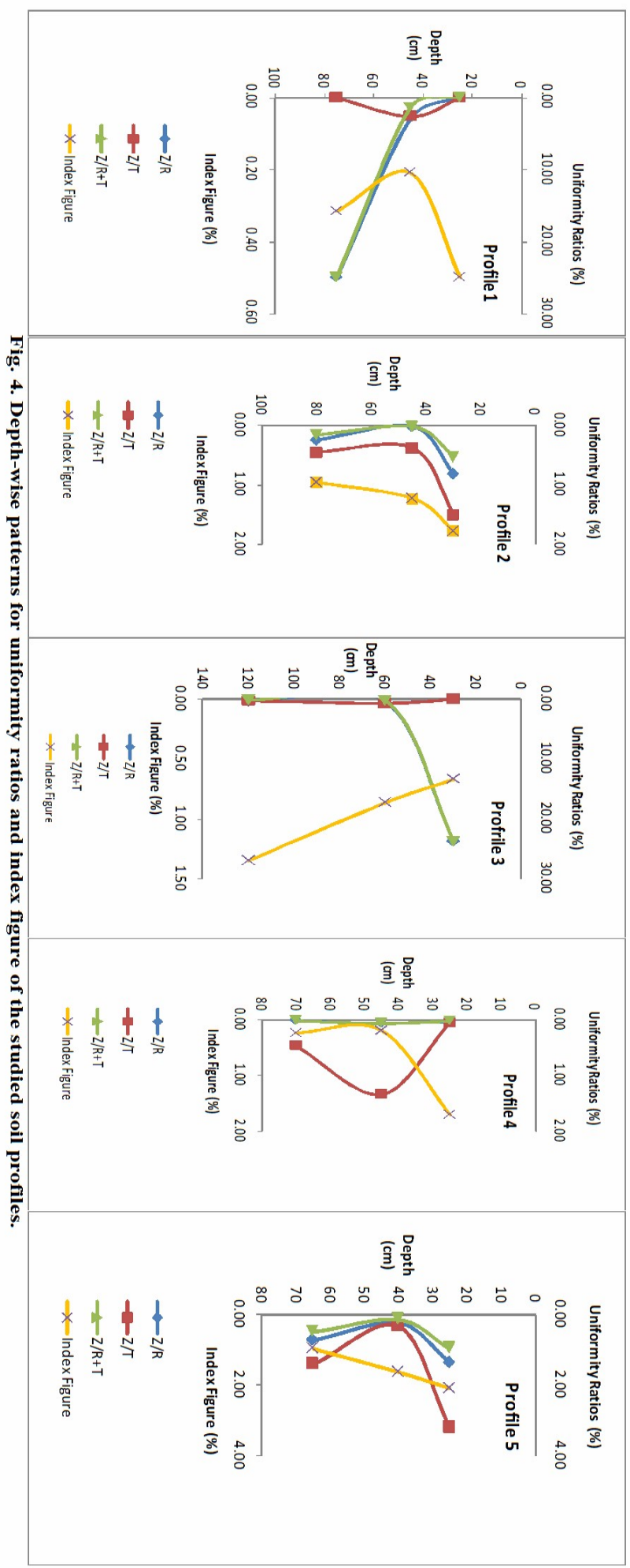




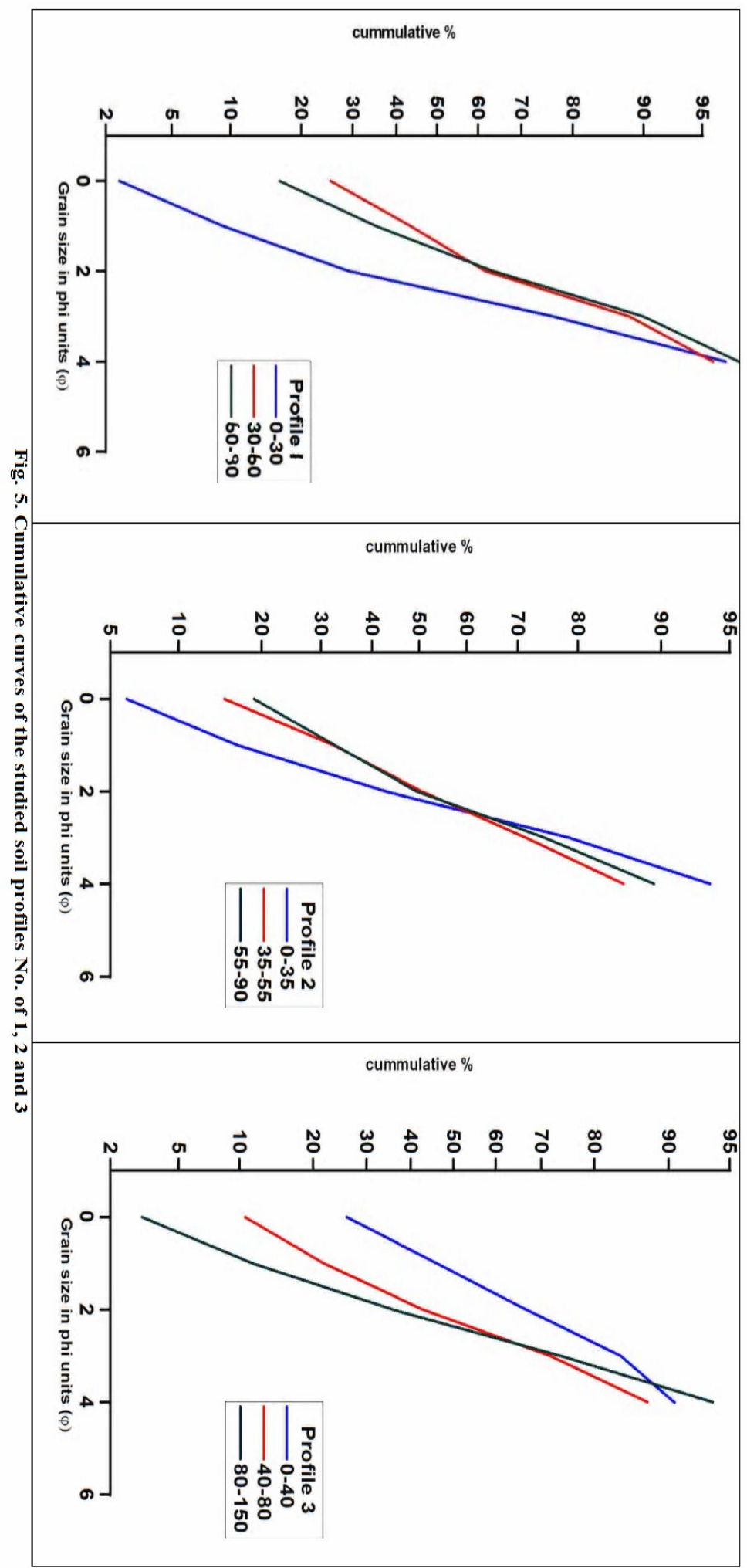




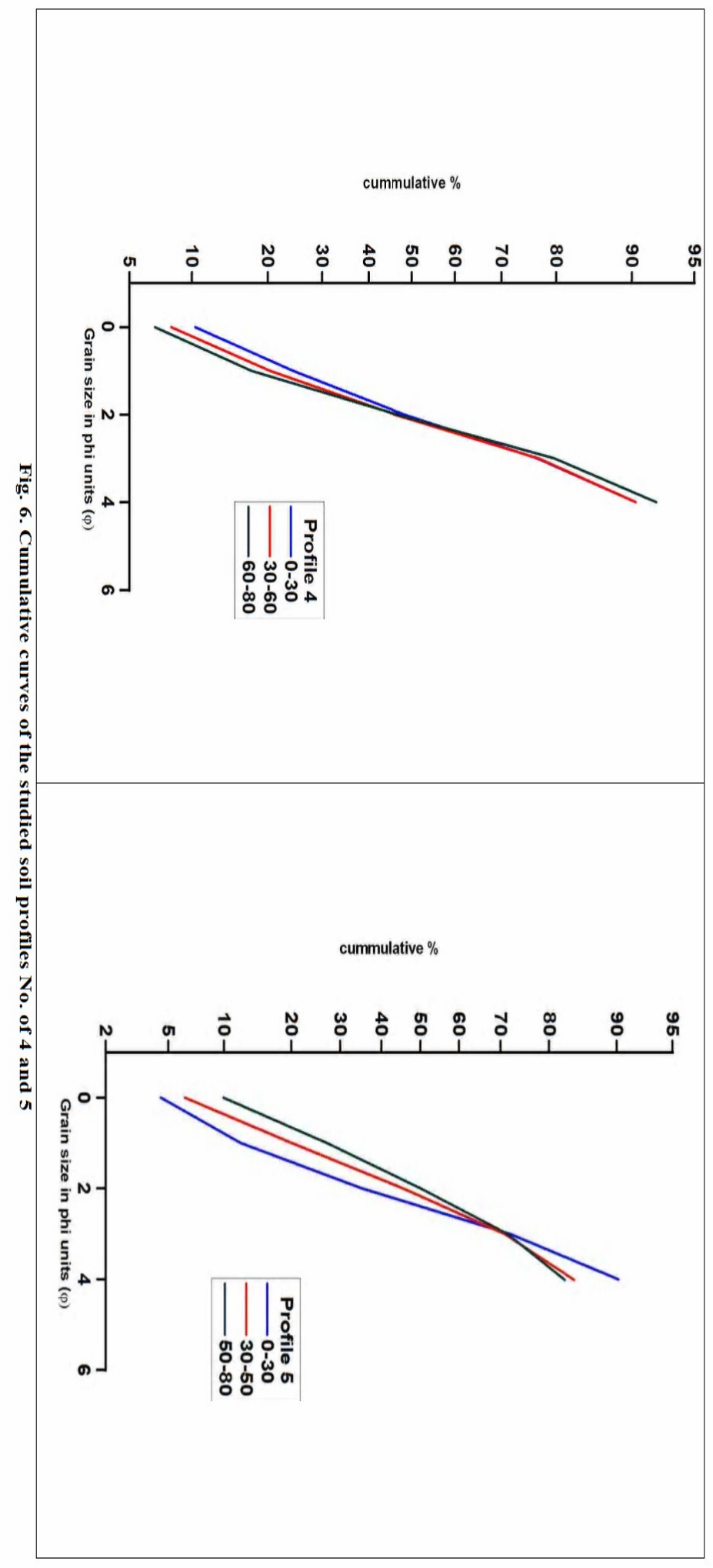




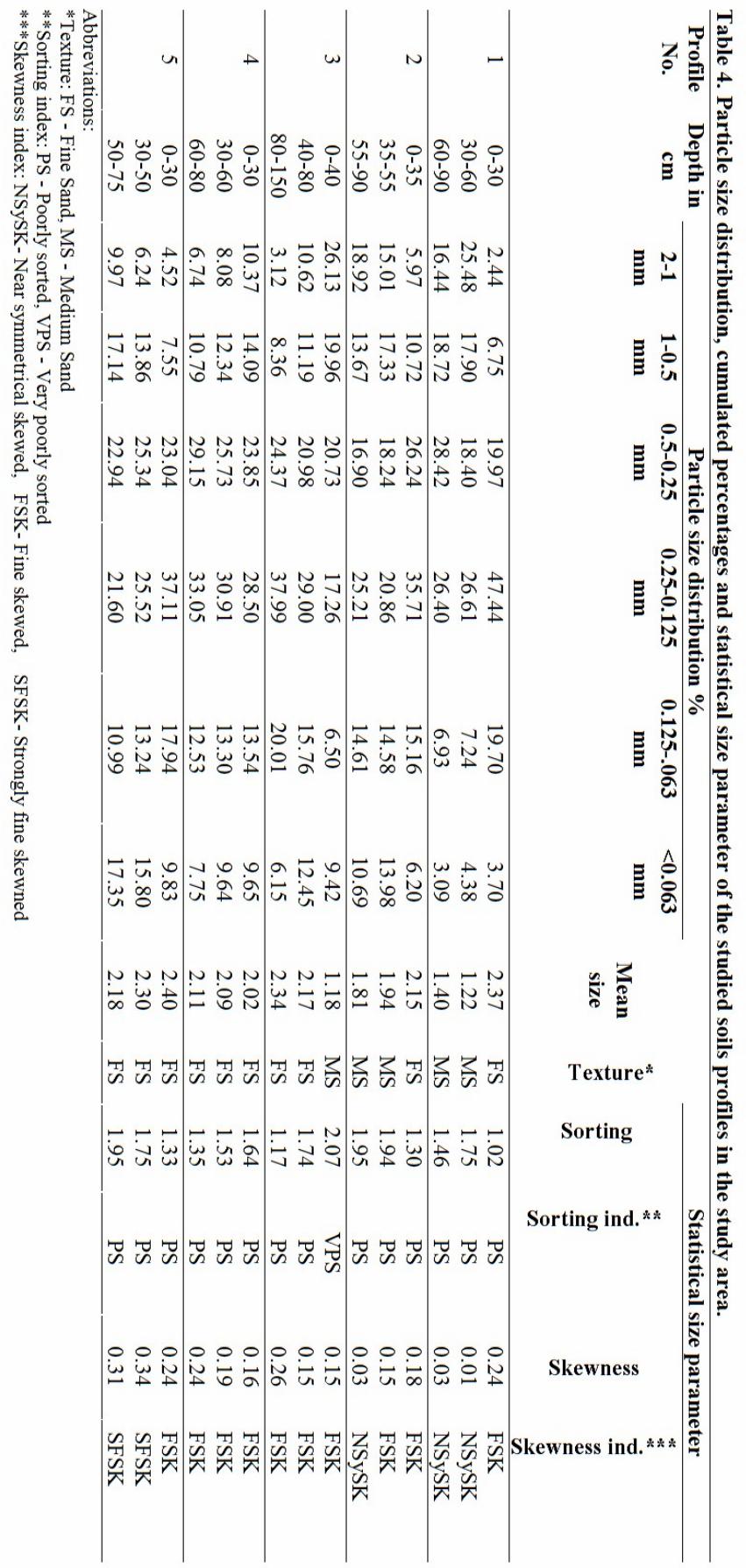




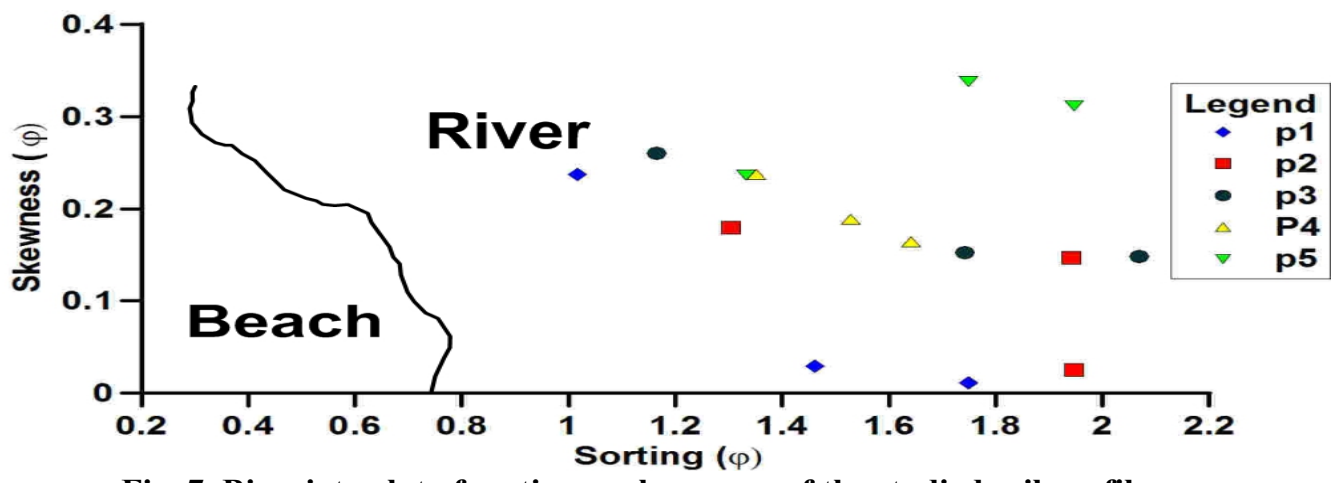

Fig. 7. Bivariate plot of sorting vs skeweness of the studied soil profiles

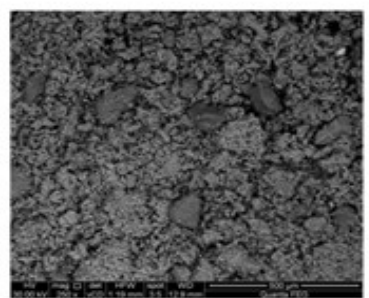

P1: $0-30 \mathrm{~cm}$

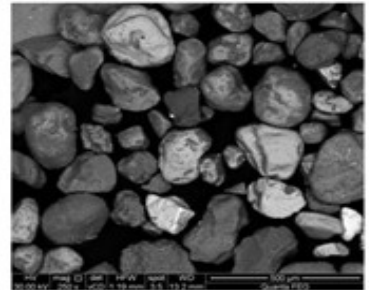

P2: $0-35 \mathrm{~cm}$

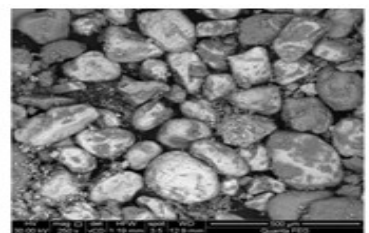

P3: $0-40 \mathrm{~cm}$

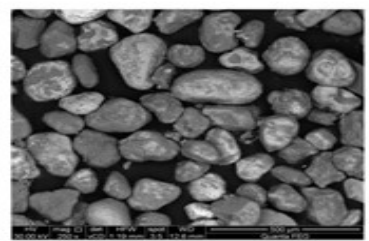

P4: 0-30 cm

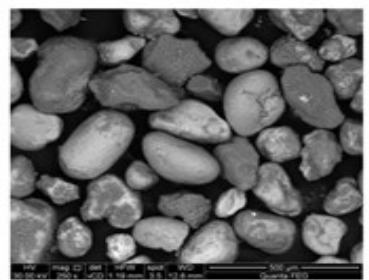

P5: $0-30 \mathrm{~cm}$

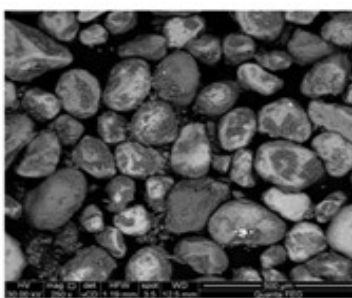

P1:30-60 cm

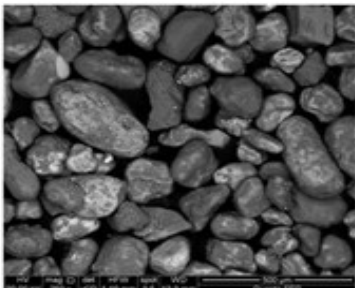

$\mathrm{P2:35-55} \mathrm{cm}$

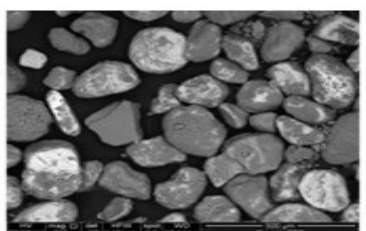

P3:40-80 cm

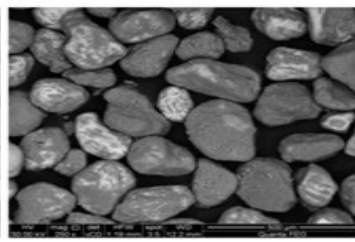

P4:30-60 cm

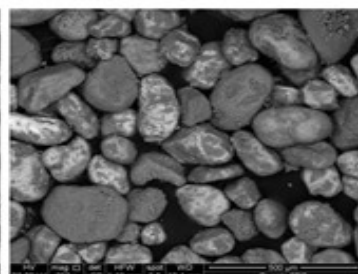

P5:30-50 cm

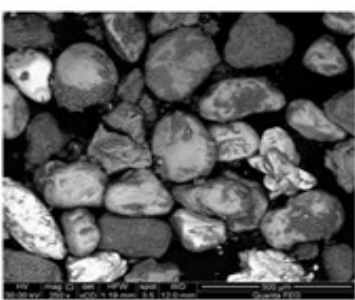

P1:60-90 cm

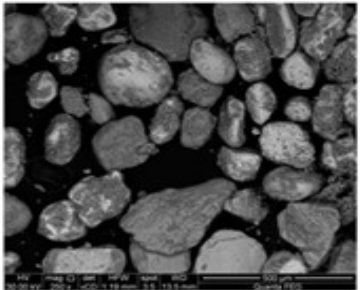

P2:55-90 cm

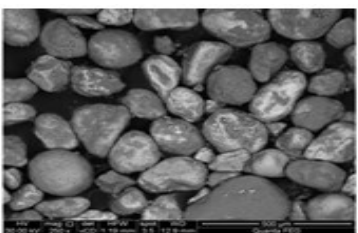

P3:80-150 cm

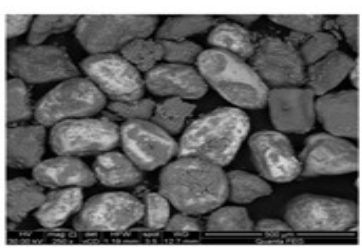

P4:60-80 cm

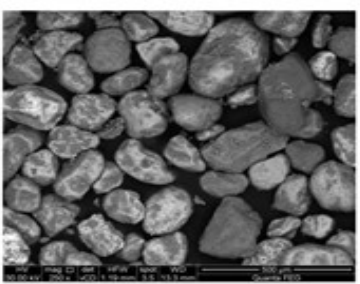

P5:50-80 cm

Plate 1. SEM micrographs of the heavy minerals in the soils of the study area 


\section{Pedogenesis and parent material uniformity appraisal}

Studying of heavy minerals is considered as criteria for establishing genesis and uniformity of soil parent material. (Haseman and Marshall, 1945; Hammad, 1968; El Kady, 2008) and many authors used the ratio between zircon/tourmaline, zircon/rutile, and zircon/ rutile+tourmaline to demonstrate uniformity or discontinuity of parent material. In the current work, the homogeneity of the parent material in the studied soil profiles is appraised by stratifying the ratios of $Z / T, Z / R$, and $\mathrm{Z} / \mathrm{R}+\mathrm{T}$ and index figure.

Data in table (3) exhibits that uniformity ratios of $\mathrm{Z} / \mathrm{T}, \mathrm{Z} / \mathrm{R}$, and $\mathrm{Z} / \mathrm{R}+\mathrm{T}$ and index figure have irregular distribution with depth in all the studied soil profiles. Correspondingly, soil parent materials of each profile are heterogeneous in nature and apparently formed of multi-depositional regimes (Fig.4). In general, data of uniformity ratios gravitate to boost the existence of lithological discontinuities specified by field morphology.

\section{Grain size analysis of sand fraction in relation to soil genesis}

Figures (5 and 6) and data in table (4) show clearly that soil parent materials are generally poorly sorted, except for the surface layer of profile (3) that is very poorly sorted. These results together with figure (7) indicate that these soils were formed under water action (fluvial deposits). Nevertheless, the depth-wise distribution of IF, ZRT, R and T show clearly that soils represented by profiles 1,4 and 5 are formed of two successive layers. The surface layer differs from the underlying rather identical sub-surface layers. On the other hand, the soils represented by profiles 2 and 3 show obvious heterogeneity, where sharp differences have been accounted and that can be attributed to multidepositional regime or inheritance from multi- parent materials.

Many investigations have utilized SEM analysis to evaluate mode of transportation and hence genesis of the sediments through the shape and surface features of the grains, (Pye and Mazzullo, 1994; Okhravi and Amini, 2001; Cherian et al., 2004; Kasper-Zubillaga et al., 2005). Accordingly, SEM micrographs of heavy minerals samples of the studied soils (Plate 1) showed particles possessing sub-rounded to sub-angular outlines which mean that sediments of the study area most probably transported and originated by water to distances not far away.

\section{CONCLUSION}

The soils under consideration displayed significant variations in the frequency distribution of the heavy minerals either among layers or sites linked to the ground elevations (100-170 m A.S.L) on the toposequence model. Soils of the study area are immature, weakly developed and impacted by geogenic processes rather than pedogenic. Subsequently, most of pedological characteristics are influenced by the parent material more than the other soil forming factors and are less affected by the prevailing environmental conditions. Soil parent materials of the research area are heterogeneous in nature and apparently formed of multidepositional regimes. The soils most likely reworked and originated by water agent to distances not far away.

\section{ACKNOWLEDGEMENT}

Authors are thanking Prof. Dr. Abdel Ghaphour E. A. for the scientific and technical revision of the paper to bring it into view.

\section{REFERENCES}

Arnold, R. W. 2008. Pedology and pedogenesis. In: Chesworth, W. (ed) Encyclopedia of Soil Science.Pp 51215.Springer, Dordrecht, Netherland.

Barshad, I. 1965. Chemistry of soil development, F.E. Bear (Ed.), Chemistry of the Soil (2nd edn.), Reinhold Publ. Co., New York (1965), pp. 1-70.

Brewer, R. 1976. Fabric and Mineral Analysis of Soils, Robert E. Krieger Publishing Co., New York.

Brewer, R. 1964. Fabric and mineral analysis of soils.John Wiley and Sons, Inc. New York, London.

Cherian, A. N. Chandrasekarand V. Rajamanickam 2004. Light minerals of beach sediments from Southern Tamilnadu, south east coast of India. Oceanologia, 46, 233-252.

Egyptian General Petroleum Corporation - Conco Coral. 1987. Geological Map of Egypt, sheet of El-Minia, Scale 1:500000.

EL Kady, M.M. 2008. Soils Distribution and Development of El Alamein - Wadi El Natrun Area, Egypt.M.Sc. Thesis, Fac. Agric., Al-Azhar University, Cairo.

El-Desooky, A.I. 2009. Studies on some soils in the area between SamalutsndBaharia Oasis - Egypt. Ph.D thesis, Fac. Agric., Al-Azhar University, Cairo.

FAO 2006. Guidelines for soil description, fourth edition, Food and Agriculture Organization of the United Nations, Rome.

Folk, R.L. and W.C. Ward 1957.Brazos River bar: a study in the significance of grain size parameters: Jour. Sed., Petrology, V. 27, p. 3-26. 
Hammad, M.A. 1968. Genesis of the soils of the Western Mediterranean Coast of U.A.R., Ph.D. Thesis, Fac. Agric., Ain Shams Univ., U.A.R.

Hammad, M. A.; A.S.A., Abdel-Mawgoud, and A.I. ElDesooky2009.Heavy mineral analysis of some soils of an old deltaic plain in western desert of Egypt. Abstract at Mansoura Journal of Agricultural Science, Mansoura Univ., Vol. 34, No. 8, p. 9173-9183.

Haseman, J.F. and C. E. Marshall 1945. The use of heavy minerals in studies of the origin and development of soils. Missouri Agr. Exp. Sta. Res. Bull. 387.

Hubert, J.F. 1962. A Zircon-Tourmaline-Rutile Maturity Index and Independence of Composition of Heavy Mineral Assemblages with Gross Composition and Texture of Sandstone. Journal of Sedimentary Petrology, $32,440-450$.

Kasper-Zubillaga, J.J.; W.W. Dickinson; A. CarranzaEdwards, and Y. Hornelas-Orozco 2005. Petrography of quartz grains in beach and dune sands of Northland, North Island, New Zealand. New Zealand Journal of Geology and Geophysics, 48, 649-660.
Keulen, N.; D. Frei; P. Riisager, and C. Knudsen 2012. Analysis of heavy minerals in sediments by Computer Controlled Scanning Electron Microscopy (CCSEM): Principles and Applications. In Quantitative Mineralogy and Microanalysis of Sediments and Sedimentary Rocks (Mineralogical Association of Canada Short Course Series 42), Mineralogical Association of Canada, Canada, 2012: 167184.

Norton, L.D. and G. F. Hall 1984.Differentiation of lithologically similar soil parent materials. SSSAJ, Vol. 49 No. 2, p. 409-414.

Okhravi, R. and A. Amini2001. Characteristics and provenance of the loess deposits of the Gharatikan watershed on Northeast Iran. Global and Planetary Change, 28, 11-22.

Pye, K. and J. Mazzullo1994. Effects of tropical weathering on quartz grain shape: an example from northeastern Australia. Journal of Sedimentary Research, A64, 500 507.

Taboada, T.; A. M. Cortizas ; C. Garcia, and E.G. Rodeja 2006. Particle-size fractionation of titanium and zirconium during weathering and pedogenesis of granitic rocks in NW Spain. Geoderma, 131 (2006), pp. 218-236.

Yossif, T.M. 2017. Soil resources potentialities of some areas adjacent to BaniMazar-El-Boiety road, West of El-Minia, Egypt. J. Adv. Agric. Res. Fac. Agric. Saba Basha. Vol. $22(3), 2017$. 


\section{الملخص العربي}

تقييم نثأة وتجانس مادة أصل بعض الأراضي المتاخمة لطريق بني مزار - البويطي، المنيا، مصر

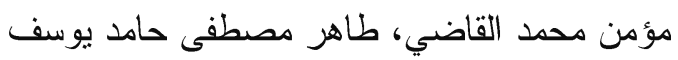

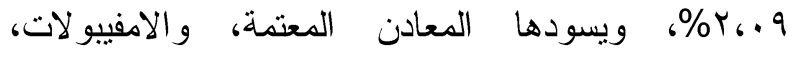

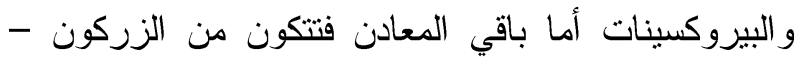
التورمالين- الروتيل- الجارنت، وقد وجدت بكميات قليلة

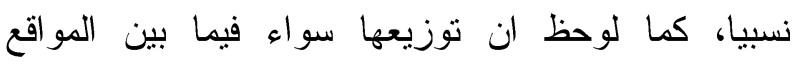

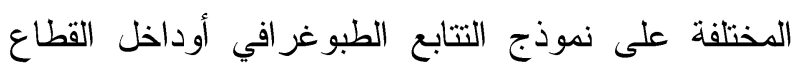
الارضي نفسه كان متأثزا ومرتبطا بالتغيرات السطحية

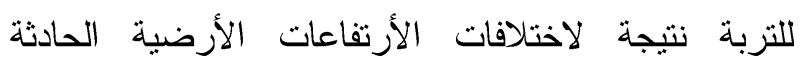

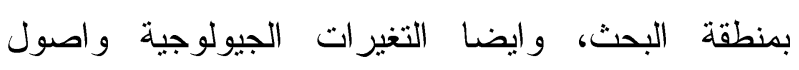
الرو اسب المختلفة.

كما بينت النتائج أن أراضي المنطقة المدروسة حديثة النشأة والتكوين وأن مظاهر التطور بها غير واضحة وغير أنان

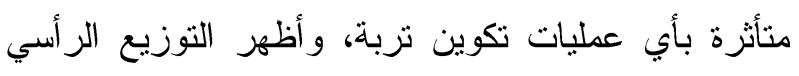

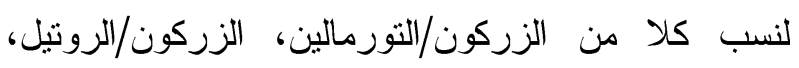
الزركون /الروتيل+التورمالين، ونسب الزبورئ المعادن التقيلة الكلية(Index Figure)_اخل القطاعات الارضية نمطا غير منتظم مع العمق مما أثبت عدم تجانس مادة اصل التزبة وتكونها نتيجة لانظمة ترسيب متعددة.هذا وقد دعمت نتائج التحليل الاحصائى لمكون الرمل النتائج السابقة. كما عكست الصور المجهرية للميكرسكوب الالكتروني الماستح من خلال الثكل الظاهري لحبيبات المعادن الثقيلــة ان اراضي منطقة البحث من المحتمل تكونها نقلا بواسطة عامل الماء ولكن من مسافات قريية.
يعتبر فهم و استيعاب تاريخ نشأة الأراضي من الخطوات الأساسية التى لاغنى عنها ويجب وضعتها في المقام الاول

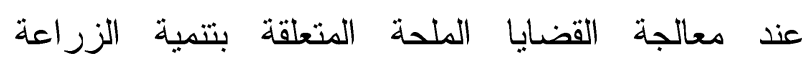
المستدامة، وتدهور التربة بالاقاليم الجافة وشديدة الجفاف لهابه كالتي تحدث بمصر، من أجل هذا اجريت الدراسة الحالية

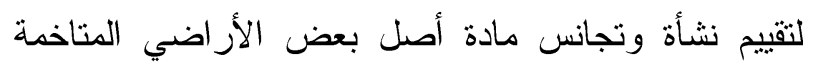
لطريق بني مزار - البويطي الممتد بصحراء غرب المنيا بمصر كونها ضمن خطة الدولة للتوسع الزر اعي باستخدام تقنية التقييم الكمي للمعادن بو اسطة الميكرسكوب الالكتروني

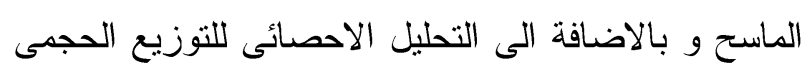

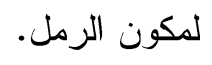
هذا وقد اختيرت خمس(0) قطاعات نزبة لتمثل منطقة الدراسة الواقعة فيما بين خطي طول

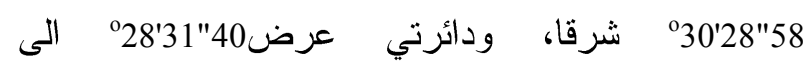

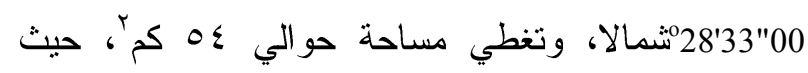
وزعت القطاعات على اساس الاختلاف في الارتفاعات الأرضية لتغطي اغلبها، حيث تراوحت فيما بين( . . 1-

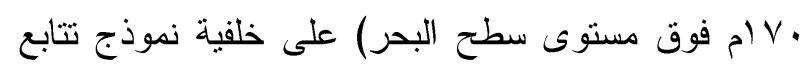
طبو غرافي تم بناءه من خريطة الارتفاعات الرقمية للمنطقة

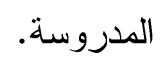

و أظهرت البيانات المتحصل عليها بواسطة التقنية

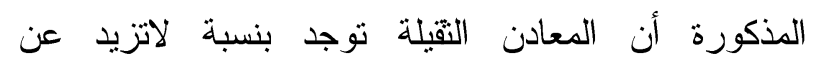

